http://doi.org/10.35784/iapgos.2812

\title{
INDIRECT INFORMATION HIDING TECHNOLOGY ON A MULTIADIC BASIS
}

\author{
Volodymyr Barannik ${ }^{1}$, Natalia Barannik ${ }^{2}$, Oleksandr Slobodyanyuk ${ }^{3}$ \\ ${ }^{1}$ V.N. Karazin Kharkiv National University, Kharkiv, Ukraine, ${ }^{2}$ National University of Civil Defence of Ukraine, Kharkiv, Ukraine, ${ }^{3}$ Kamianets-Podilskyi Ivan Ohiienko \\ National University, Kamianets-Podilskyi, Ukraine
}

\begin{abstract}
It is shown that the current direction of increasing the safety of information resources when transmitting information in info-communication systems is the use of methods of steganographic instruction in video imagery. The effectiveness of such methods is significantly increased when used in a complex of methods of concealment, which are based on the principles of inconsistent and cosmic communication. At the same time, existing methods of steganographic are used in the process of insertion of information mainly only laws, empty features of visual perception of video images. So, it is justified that the scientific and applied problem, which is to increase the density of embedded messages in the video container with a given level of their reliability, is relevant. The solution of this problem is based on the solution of the contradiction, which concerns the fact that increasing the density of embedded data leads to a decrease in the bit rate of the video container, steganalysis stability, reliability of special information, and video container. Therefore, the research aims to develop a methodology for the steganographic embedding of information, taking into account the regularities of the video container, which are generated by its structural and structural-statistical features. The solution to the posed problem of applying steganographic transformations is proposed to be realised by methods of indirectly embedding parts of the hidden message in certain conditions or functional relationships. The possibility of creating steganographic transformations regarding the indirect embedding and extraction of hidden information in a multiadic basis by modifying the underlying basis system within an admissible set is demonstrated. It is shown that the multiadic system, which is created in the spectral space of DCT transforms, has the potential to form a set of admissible modifications of basis systems.
\end{abstract}

Keywords: steganographic transformations, video container, video compression, indirect embedding

\section{TECHNOLOGIA POŚREDNIEGO UKRYWANIA INFORMACJI NA ZASADZIE MULTIADYCZNEJ}

Streszczenie. Wykazano, że aktualnym kierunkiem zwiększania bezpieczeństwa zasobów informacyjnych przy przesyłaniu informacji w systemach infokomunikacyjnych jest stosowanie metod instrukcji steganograficznej w obrazach wideo. Skutecznośc tych metod znacznie wzrasta, gdy sa one stosowane $w$ zespole metod ukrywania, które opieraja się na zasadach bezpośredniego i pośredniego osadzania komunikatów. Jednocześnie istniejace metody steganografii wykorzystuja $w$ procesie osadzania informacji głównie wzorce generowane przez cechy percepcji wizualnej obrazów wideo. Tak więc, uzasadnione jest, że istotnym jest problem naukowy i praktyczny polegajacy na zwiększeniu gęstości osadzonych wiadomości w kontenerze wideo z danym poziomem ich wiarygodności. Sednem tego problemu jest rozwiąanie kontrowersji, że wzrost gęstości osadzonych danych prowadzi do spadku przeplywności kontenera wideo, odporności na steganoanalizę, wiarygodności informacji specjalnych $i$ kontenera wideo. Dlatego celem pracy jest opracowanie metodyki steganograficznego osadzania informacji uwzględniajacej prawa kontenera wideo, które sa generowane przez jego cechy strukturalne i konstrukcyjno-statystyczne. Rozwiazanie postawionego problemu w zakresie zastosowania przekształcen steganograficznych proponuje się zrealizować metodami pośredniego osadzania części ukrytego komunikatu w pewnych warunkach lub zależności funkcjonalnych. Wykazano możliwość tworzenia przeksztatceń steganograficznych odnośnie pośredniego wbudowania i ekstrakcji ukrytych informacji w bazie wieloaddycznej poprzez modyfikacje podstawowego układu bazowego $w$ ramach dopuszczalnego zbioru. Udowodniono, ze uktad wieloadyczny, który powstaje $w$ przestrzeni spektralnej transformat DCT, ma potencjał do tworzenia zbioru dopuszczalnych modyfikacji układów bazowych.

Słowa kluczowe: transformacje steganograficzne, kontener wideo, kompresja wideo, pośrednie osadzanie

\section{Introduction}

One of the actual directions for increasing the security of information resources during transmission in info-communication systems is the use of methods of steganographic embedding of information in video images. The efficiency of such methods significantly increases when used in a set of concealment methods, which are based on the principles of direct and indirect embedding of messages. It allows [1-3] to create conditions for localizing the imbalance between the timeliness of the delivery of hidden information (special information) and the indicator of its reliability $[4,5,7,8]$.

At the same time, the existing methods of steganography are used in the process of embedding information mainly only the regularities generated by the features of visual perception of video images. In turn, this leads to the fact that with the use of modern telecommunication technologies and coding technology video container H26* creates conditions for the organization of the hidden message channel, which allows you to embed a message at $3-20$ Mpixels for PSNR in $20 \mathrm{~dB}$. This accordingly creates conditions for hiding FullHD video images [9-11]. However, in this case, the level of PSNR is $20 \mathrm{~dB}$, which means that there are significant distortions of the video container. So, such PSNR level does not satisfy the required level of video information fidelity in critical infrastructure management systems. On the contrary, for a given level of fidelity (the PSNR value reaches $40 \mathrm{~dB}$ ) conditions are created for hiding messages with a bit volume of only 1.5 Mbytes. This allows hiding CIF and SD format video images. But this format of video images does not meet the requirements regarding the completeness of video information [12-16].
So, the scientific and applied problem, which is to increase the density of embedded messages in the video container with a given level of reliability, is relevant.

The solution to this problem is based on the solution of a contradiction, which concerns the fact that increasing the density of embedded data leads to a decrease in the bit rate of the video container, steganalysis stability, reliability of special information, and video container $[15,17,18]$.

To resolve this contradiction, it is proposed to develop steganographic methods that allow message embedding under conditions of exclusion of necessity (or limitation) in the use of psychovisual regularities. That is, the process of message embedding should not be accompanied by additional distortions in the video container [19-21].

Therefore, the purpose of the study is the development of the methodology of steganographic information with the take into account the regularities of the video container, which are empty of its structural and structural-statistical characteristics.

\section{The reasoning of the direction for creating steganographic systems with video container distortion exclusion}

The solving of the formulated problem in the field of application of steganographic transformations is proposed to realize with the use of methods of indirect embedding of some condition or functional dependence to the bit of scrambled message [22-26].

But in turn, the existing methods of indirect steganographic transformations are characterized by a drawback, which is the 
insufficient value of the density of embedded data according to modern requirements $[25,27,28]$.

To eliminate the disadvantages of indirect steganographic embedding, it is proposed to develop an approach that allows using not only psychovisual but also structural redundancy of video containers for concealment [6, 29-33].

To build a steganographic system under the conditions of fulfilling the requirements, it is proposed to use multiadic transformation [35-37]. In this case, the following is achieved.

1. The regularities appear adaptively for each data set with the structural-combinatorial origin and are described quantitatively in the form of estimates of the dynamic ranges of the data set elements. That is.

$$
\psi_{i}=\max _{1 \leq i \leq m}\left\{a_{i, j}\right\}+1 \quad j=\overline{1, n} .
$$

here $a_{i, j}-j$-th item $i$-th row of the array $A$.

2. There is a possibility of restored data array elements to establish with given integrity of the appropriate conditional dependence. This provides a condition for extracting a hidden message without loss of information [38, 39].

In this case, the process of removing hidden information will be carried out by analyzing the values of the initial and modified service information.

Modifications in the field of structural-combinator patterns create an opportunity to avoid its impact on the value of video elements. Therefore, there is potential relative to the avoidance of distortions in the masses of video data [40,41].

The data array is proposed to be considered as a container for indirect embedding information in the spectral region. This is because the DCT transformant creates conditions for identifying and reducing more structural and combinatorial redundancy than in the space-time domain [42, 43]. Consequently, DCT transformants increase the potential for the embedding of the hidden message due to modification in the field of patterns according to dynamic ranges in the conditions of the presence of the corresponding amount of structural and combinatorial redundancy.

Thus, a selection of a multiadic system is substantiated to organize indirect hiding information in terms of avoidance of losses as built-in information, and additional distortion of the container.

\section{Creation of methodology of the steganographic system of indirect hiding information.}

Multiadic system (MAS) - system $F_{\text {mads }}\left(A_{j} ; E_{j} ; \Psi ; \delta_{j}=0\right)$ mutual one-to-one $\left(\delta_{j}=0\right)$ formation of code values $E_{j}$ for sequences $A_{j}$ in multiadic space with the set system of bases $\Psi$. Here $\delta_{j}-$ average deviation of elements of decoded multiadic number relative to elements of initial IODM number. This is described by the expression:

$$
\delta_{j}=\sqrt{\frac{\sum_{i=1}^{m}\left(a_{i, j}^{(\theta)}-a_{i, j}\right)^{2}}{m}},
$$

where $m$ - number of elements in multiadic number;

$a_{i, j}^{(\theta)}-(i ; j)$-th item for $\theta$-th an option to recover the initial multiadic number $A_{j}$;

$A_{\theta, j}-j$-th multiadic number for $\theta$-th variant of system building $\Psi_{\theta}$ basis, $A_{\theta, j}=\left(a_{1, j}^{(\theta)} ; \ldots ; a_{i, j}^{(\theta)} ; \ldots ; a_{m, j}^{(\theta)}\right)$.

The multiadic system consists of two basic operators $\phi_{\text {emad }}\left(A_{j} ; \Psi\right), \phi_{\text {dmad }}\left(E_{j} ; \Psi\right)$. Therefore:

$$
F_{\text {mads }}\left(A_{j} ; E_{j} ; \Psi ; \delta_{j}=0\right)=\left\{\phi_{\text {emad }}\left(A_{j} ; \Psi\right) ; \phi_{\text {dmad }}\left(E_{j} ; \Psi\right)\right\} \text {. }
$$

Here $\phi_{\text {emad }}\left(A_{j} ; \Psi\right), \quad \phi_{\text {dmad }}\left(E_{j} ; \Psi\right)$ - operators, which are implemented according to the technology of direct (encoding) and reverse (decoding) of multiadic transformations.

Let's introduce the concept of basic MAS. The basic (reference) multiadic system is understood as such a system that is formed directly for a particular data set (video data block, transformant).

So, in this case, the basic system $\Psi$ of bases $\psi_{i}$ is such a system, the values of bases of which are determined by the rules of:

$$
\psi_{i}=\max _{1 \leq j \leq n}\left\{a_{i, j}\right\}+1, i=\overline{1, m}
$$

That is, the value of bases $\psi_{i}$ for the base system $\Psi$ is defined as dynamic ranges of elements in the rows of the data array.

Defining the basics $\psi_{i}$ by dynamic range not for individual elements $a_{i, j}$ multiadic numbers, but by the set of elements in rows, i.e. $A_{i}=\left\{a_{i, 1} ; \ldots ; a_{i, j} ; \ldots ; a_{i, n}\right\}$, due to the need to reduce the bit volume of the service component. Then, on average, each element of the column of the data array (transformers) will fall on average $\left(\log _{2} \psi_{i} / n\right)$ binary digits. Wherefore, as the number of columns grows, the value $\left(\log _{2} \psi_{i} / n\right)$ will decrease. Therefore, the total bit volume of the compression representation of the data array (transformers) will be reduced as a result of the multiadic encoding of its columns.

It is clear that for the possibility of indirect concealment of information in a multiadic system at the level of structural meta-features, MAS must possess the following property (characteristic).

\section{Property of MAS}

Multiadic System Property (MASP) on the possibility of forming and without erroneous restoration of one multiadic number $A_{j}$ by multiple code values $E_{\theta, j}$ in a different system of bases $\Psi_{\theta}$.

That is, relative to the error-free direct and inverse transformations of a single multiadic number $A_{j}$ in various multiadic systems $F_{\text {mads }}\left(A_{j} ; E_{j} ; \Omega(\Psi) ; \delta_{j}=0\right)$. Here $\Omega(\Psi)$ - a set of multiadic bases $\Psi_{\theta}$, for which this MAS property is provided.

To prove this property of MAS, we will formulate and then prove the following statement.

To generalize the conclusions of the statement, we will carry out its examination without reference to a specific transformation or a set of video data. There is $A_{j}$ initial one-dimensional multiadic (IODM) number, $A_{j}=\left\{a_{1, j} ; \ldots ; a_{i, j} ; \ldots ; a_{m, j}\right\}$ in a basis $\Psi=\Psi_{\theta}$ of bases $\psi_{i}=\psi_{i}^{(\theta)}, i=\overline{1, m}$, for which is the code value $E_{j}=E_{\theta, j}$.

So in this case this formulation of the statement corresponds.

The statement about the existence of a plurality of admissible multiadic systems for one sequence (about the modification of the system of bases).

There are so set of systems $\Omega(\Psi)$ of bases $\Psi_{\theta}, \theta=\overline{1, \Theta}$, for which with the help of the set $\Omega(E)$ corresponding code values $E_{\theta, j}, \quad \theta=\overline{1, \Theta}$ for one sequence $A_{j}$ mutually unambiguous (without false) direct and reverse multiadic transformation is achieved, namely:

$$
A_{j}=\phi_{\text {dmad }}\left(E_{\theta, j} ; \Psi_{\theta}\right) \text {, for } E_{\theta, j}=\phi_{\text {emad }}\left(A_{j} ; \Psi_{\theta}\right)
$$


There is $W_{\theta, i}$ - a weight coefficient of the i-th element of the sequence $A_{j}$ in case of use $\theta$-th variant of system bases construction $\Psi_{\theta}$.

This statement allows establishing the conditions of modification of the system of bases of the multiadic space, for which restoration of elements of the initial sequence without loss of information is provided. So there's a set $\Omega(\Psi)$ of variants of system basis modifications $\Psi_{\theta}$, which eliminates the loss of information in the process of reconstruction of elements of multiadic (IODM) numbers using the corresponding code values. The mutual one-valued conversion between the code values $E_{\theta, j}$ and related IODM number $A_{j}$ will be executed in the case of:

- the choice of the system of bases $\Psi_{\theta}$, which is included in the admissible set $\Omega(\Psi)$ of options for the construction of;

- the formation of appropriate code values $E_{\theta, j}$ in the permissible systems of bases $\Psi_{\theta}$.

In the particular case of two admissible systems of bases $\Psi_{\theta}$, $\Psi_{\vartheta}$, i.e. $\Psi_{\vartheta}, \Psi_{\theta} \in \Omega(\Psi), \theta \neq \vartheta$, in the conditions of the formation of code values by expressions:

$$
E_{\theta, j}=\phi_{\text {emad }}\left(A_{j} ; \Psi_{\theta}\right) ; \quad E_{\vartheta, j}=\phi_{\text {emad }}\left(A_{j} ; \Psi_{\vartheta}\right)
$$

will be achieved decoding the original sequence without loss of information, such as:

$$
\phi_{\text {dmad }}\left(E_{\theta, j} ; \Psi_{\theta}\right)=\phi_{\text {dmad }}\left(E_{\vartheta, j} ; \Psi_{\vartheta}\right)=a_{i, j} \in A_{j}, \quad i=\overline{1, m}, j=\overline{1, n} \text {. }
$$

At the same time, it should be taken into account that according to the technological requirements for digitization of full-color video images, the element values of each color component cannot exceed the value of 255 . Then the dynamic range of each element will be in the following limits: $0 \leq a_{i, j} \leq 255$.

What is the meaning of base $\psi_{i}^{(\theta)}$ will be limited to a maximum value of 256 , such as:

$$
a_{i, j} \leq \psi_{i}^{(\theta)}-1 \leq 255, \quad i=\overline{1, m}
$$

The inequalities (1) describe the conditions for the formation of an admissible set of $\Omega(\Psi)$ systems of $\Psi_{\theta}$ bases, which creates conditions for the construction of mutually one-valued multiadic systems.

From expression (1) we obtain the value ${ }_{\Delta} \psi_{i}^{(\theta)}$, which defines the range of acceptable changes in the values of the bases relative to the elements $a_{i, j}$ multiadic number, i.e.

$$
{ }_{\Delta} \psi_{i}^{(\theta)} \leq 256-\psi_{i}^{(\theta)}
$$

In general, we obtain the following relation, which limits the values of the quantities ${ }_{\Delta} \psi_{i}^{(\theta)}$ :

$$
1 \leq{ }_{\Delta} \psi_{i}^{(\theta)} \leq 256-\psi_{i}^{(\theta)}
$$

This allows us to determine the volume $|\Omega(\Psi)|$ of the acceptable systems of the basics set $\Omega(\Psi)$ in relation to the values of the elements $a_{i, j}$ IODM number, such as:

$$
|\Omega(\Psi)|=\Theta=\prod_{i=1}^{m}\left({ }_{\Delta} \psi_{i}^{(\theta)}-1\right)
$$

From the analysis of formula (2), it follows that $|\Omega(\Psi)|>1$ if $\left({ }_{\Delta} \psi_{i}^{(\theta)}-1 \geq 1\right)$. The last condition is reached when $a_{i, j}<<255$ that is when elements of multiadic numbers have a limited dynamic range $\psi_{i}^{(\theta)}$. The volume of the set $\Omega(\Psi)$ depends on the amount of structural-combinatorial redundancy generated by the finiteness of the dynamic ranges of the elements of multiadic numbers.
At the same time, as practical studies show, the formation of a multiadic basis in the spectral space using the discrete cosine transform (DCT) provides the presence of patterns of such origin.

It follows that the multiadic system, which is created in the spectral space of the transformant DCT, has the potential for the formation of a set of admissible modifications of the systems of bases. In turn, this characteristic feature creates the possibility for the construction of indirect steganographic transformations on the multiadic basis based on a modification of structural meta-features

\section{Conclusions}

1. It has been proven that it is possible to create steganographic transformations to indirect embedding and removal of hidden information on a multiadic basis by modifying the basic system of bases within the permissible set.

2. There has been a proven existence of multiple permissible multiadic systems for the same continuity in a way that achieves mutually unambiguous (without erroneous) direct and reverse code transformation. This allows you to establish the conditions for modifying the system of multiadic space for which the recovery of the elements of the initial sequence without loss of information, namely:

- selection of the system of bases, which is part of the permissible set of constructing options;

- formation of the corresponding code values in allowable systems of bases.

3. It is substantiated that the multiadic system that is created in the spectral space transformant DCT has the potential for the formation of a set of permissible modifications of bases. In turn, such a characteristic feature creates an opportunity to build indirect steganographic transformations in a multiadic based on the modification of structural meta-features.

\section{References}

[1] Alam, M. A.: Faster Image Compression Technique Based on LZW Algorithm Using GPU Parallel Processing. Joint 7th International Conference on Informatics, Electronics \& Vision (ICIEV) and 2nd International Conference on Imaging, Vision \& Pattern Recognition (icIVPR), 2018, 272-275 [http://doi.org/10.1109/ICIEV.2018.8640956].

[2] Announcing the ADVANCED ENCRYPTION STANDARD (AES), Federal Information Processing Standards Publication 197, 2001.

[3] Barannik V.: Fast Coding of Irregular Binary Binomial Numbers with a Set Number of Units Series. IEEE 2nd International Conference on Advanced Trends in Information Theory (IEEE ATIT 2020), 2020, 29-33 [http://doi.org/10.1109/ATIT50783.2020.9349356].

[4] Barannik D.: Stegano-Compression Coding in a Non-Equalible Positional Base. IEEE 2 nd International Conference on Advanced Trends in Information Theory, 2020, 83-86 [http://doi.org/10.1109/ATIT50783.2020.9349328].

[5] Barannik N., Ryabukha Yu.: Method of Indirect Steganographic Coding of Information without Visual Distortion of the Video Container series. IEEE 2 nd International Conference on Advanced Trends in Information Theory, 2020, 57-61 [http://doi.org/10.1109/ATIT50783.2020.9349262].

[6] Barannik V., Hahanova A., Krivonos V.: Coding tangible component of transforms to provide accessibility and integrity of video data. International Symposium, East-West Design \& Test Symposium (EWDTS), 2013, 1-5 [http://doi.org/10.1109/EWDTS.2013.6673179].

[7] Barannik V. V., Karpinski M. P., Tverdokhleb V. V., Barannik D. V., Himenko V. V., Aleksander M.: The technology of the video stream intensity controlling based on the bit-planes recombination. 4th IEEE International Symposium on Wireless Systems within the International Conferences on Intelligent Data Acquisition and Advanced Computing Systems (IDAACSSWS), 2018, 25-28 [http://doi.org/10.1109/IDAACS-SWS.2018.8525560].

[8] Barannik V., Barannik D., Fustii V., Parkhomenko M.: Technology for Protecting Video Information Resources in the Info-Communication Space. IEEE 3rd International Conference on Advanced Information and Communications Technologies (IEEE AICT 2019), 2019, 248-250 [http://doi.org/10.1109/AIACT.2019. 8847820].

[9] Barannik, V., Barannik, N., Ryabukha, Yu., Barannik, D. Indirect Steganographic Embedding Method Based On Modifications of The Basis of the Polyadic System. 15 th IEEE International Conference on Modern Problems of Radio Engineering, Telecommunications and Computer Science, 2020, 699-702 [http://doi.org/10.1109/TCSET49122.2020.235522].

[10] Barannik V., Himenko V., Babenko Yu., Hahanova A., Fustii V.: Technology of Composite Code Forming in The Spatial-Spectral Description Significant Microsegments. IEEE 15th International Conference on Advanced Trends in Radioelectronics, Telecommunications and Computer Engineering, 2020, 703-706 [http://doi.org/10.1109/TCSET49122.2020.235523]. 
[11] Barannik V., Jancarczyk D., Babenko Yu., Stepanko O., Nikodem J., Zawislak S.: A Model for Representing Significant Segments of a Video Image Based on Locally Positional Coding on a Structural Basis. IEEE 5nd International Symposium on Smart and Wireless Systems within the Conferences on Intelligent Data Acquisition and Advanced Computing Systems (IEEE IDAACS-SWS 2020), 2020, 1-5 [http://doi.org/10.1109/IDAACS SWS50031.2020.9297068].

[12] Barannik V., Kharchenko N., Othman Shadi O., Musienko A.: A method to control bit rate while compressing predicted frames. IEEE International Conference on The Experience of Designing and Application of CAD Systems in Microelectronics (IEEE CADSM 2015), 2015, 36-38 [http://doi.org/10.1109/CADSM.2015.7230789].

[13] Barannik V., Kharchenko N., Tverdokhleb V., Kulitsa O.: The issue of timely delivery of video traffic with controlled loss of quality. 13th International Conference on Modern Problems of Radio Engineering, Telecommunications and Computer Science (TCSET), 2016, 902-904 [http://doi.org/10.1109/TCSET.2016.7452220].

[14] Barannik V., Shulgin S., Krasnorutsky A., Slobodyanyuk O., Gurzhii P., Korolyova N.: Methodological Fundamentals of Deciphering Coding of Aerophotography Segments on Special Equipment of Unmanned Complex. IEEE 2 nd International Conference on Advanced Trends in Information Theory, 2020, 38-43 [http://doi.org/10.1109/ATIT50783.2020.9349257].

[15] Barannik V., Sidchenko S., Barannik N., Khimenko A.: The method of masking overhead compaction in video compression systems. Radioelectronic and Computer Systems 2, 2021, 51-63. [https://doi.org/10.32620/reks.2021.2.05].

[16] Belikova T.: Decoding Method of Information-Psychological Destructions in the Phonetic Space of Information Resources. Proceedings of the 2nd IEEE International Conference Advanced Trends in Information Theory (ATIT), 2020, 87-91 [https://ieeexplore.ieee.org/document/9349300].

[17] Bui V., Chang L., Li D., Hsu L., Chen M.: Comparison of lossless video and image compression codecs for medical computed tomography datasets. IEEE International Conference on Big Data, 2016 3960-3962 [http://doi.org/10.1109/BigData. 2016.7841075].

[18] Chen T.-H., Wu Ch.-S.: Efficient multi-secret image sharing based on Boolean operation. Signal Processing 91(1), 2011, 90-97 [http://doi.org/10.1016/j.sigpro.2010.06.012].

[19] Deshmukh M., Nain N., Ahmed M.: An (n, n)-Multi Secret Image Sharing Scheme Using Boolean XOR and Modular Arithmetic. IEEE 30 th International Conference on Advanced Information Networking and Applications (AINA), 2016, 690-697 [http://doi.org/10.1109/aina.2016.56].

[20] Djelouah A., Campos J., Schaub-Meyer S., Schroers C.: Neural Inter-Frame Compression for Video Coding. IEEE/CVF International Conference on Computer Vision (ICCV), 2019, 6420-6428 [http://doi.org/10.1109/ICCV.2019.00652].

[21] Dong W., Wang J.: JPEG Compression Forensics agains Resizing. IEEE Trustcom/BigDataSE/IBSPA, 2016, 1001-1007 [http://doi.org/10.1109/TrustCom.2016.0168].

[22] Gonzales R. C., Woods R. E.: Digital image processing. Prentice Inc., Upper Saddle River 2002

[23] Honda T., Murakami Y., Yanagihara Y., Kumaki T., Fujino T.: Hierarchica image-scrambling method with scramble-level controllability for privacy protection. IEEE 56th International Midwest Symposium on Circuits and Systems, 2013, 1371-1374 [http://doi.org/10.1109/MWSCAS.2013.6674911].

[24] Ieremeiev O., Lukin V., Okarma K.: Combined visual quality metric of remote sensing images based on neural network. Radioelectronic and computer systems 4, 2020, 4-15 [http://doi.org/10.32620/reks.2020.4.01].

[25] Information technology - JPEG 2000 image coding system: Secure JPEG 2000 , International Standard ISO/IEC 15444-8, ITU-T Recommendation T.807, 2007.

[26] JPEG Privacy \& Security Abstract and Executive Summary, 2015 [https://jpeg.org/items/20150910_privacy_security_summary.html].

[27] Komolov D., Zhurbynskyy D., Kulitsa O.: Selective Method For Hiding of Video Information Resource In Telecommunication Systems Based on Encryption of Energy-Significant Blocks of Reference I-Frame. 1 st International Conference on Advanced Information and Communication Technologies (AICT'2015), 2015, 80-83.

[28] Li F., Krivenko S., Lukin V.: Two-step providing of desired quality in lossy image compression by SPIHT. Radioelectronic and computer systems 2, 2020 22-32 [http://doi.org/10.32620/reks.2020.2.02].

[29] Naor M., Shamir A.: Visual Cryptography. Proceedings of the Advances in Cryptology - EUROCRYPT'94. Lecture Notes in Computer Science 950, 1995, 1-12 [http://doi.org/10.1007/bfb0053419].

[30] Narmatha C., Manimegalai P., Manimurugan S.: A LS-compression schem for grayscale images using pixel based technique. International Conference on Innovations in Green Energy and Healthcare Technologies (IGEHT), 2017, 1-5 [http://doi.org/10.1109/IGEHT.2017.8093980].

[31] Richter T.: Error Bounds for HDR Image Coding with JPEG XT. Data Compression Conference, 2017, 122-130 [http://doi.org/10.1109/DCC.2017.7].

[32] Rippel O.: Learned Video Compression. IEEE/CVF International Conference on Computer Vision (ICCV), 2019, 3453-3462 [http://doi.org/10.1109/ICCV.2019.00355].
[33] Rivest R. L., Shamir A., Adleman L. M.: A method for obtaining digital signatures and public-key cryptosystems. Communications of the ACM 21(2), 1978, 120-126 [http://doi.org/10.1145/359340.359342].

[34] Sharma R., Bollavarapu S.: Data Security using Compression and Cryptography Techniques. International Journal of Computer Applications 117(14), 2015, 15-18 [http://doi.org/10.5120/20621-3342].

[35] Wang S., Kim S. M., Yin Z., He T. Encode when necessary: Correlated network coding under unreliable wireless links. ACM Transactions on Senso Networks 13(1), 2017, article 7, 1-22 [http://doi.org/10.1145/3023953].

[36] Wang S., Zhang X., Liu X., Zhang J., Ma S., Gao W.: Utility Driven Adaptive Preprocessing for Screen Content Video Compression. IEEE Transactions on Multimedia 19(3), 2017, 660-667.

[37] Wang X., Xiao J., Hu R., Wang Z.: Cruise UAV Video Compression Based on Long-Term Wide-Range Background. Data Compression Conference (DCC), 2017, 466-467 [http://doi.org/10.1109/DCC.2017.71].

[38] Watanabe O., Uchida A., Fukuhara T., Kiya H.: An Encryption-thenCompression system for JPEG 2000 standard. IEEE International Conference on Acoustics, Speech and Signal Processing (ICASSP), 2015, 1226-1230 [http://doi.org/10.1109/ICASSP.2015.7178165].

[39] Wu H., Sun X., Yang J., Zeng W., Wu F.: Lossless Compression of JPEG Coded Photo Collections. IEEE Transactions on Image Processing 25(6), 2016 , 2684-2696 [http://doi.org/10.1109/TIP.2016.2551366].

[40] Xiao W., Wan N., Hong A., Chen X.: A Fast JPEG Image Compression Algorithm Based on DCT. IEEE International Conference on Smart Cloud, 2020, 106-110 [http://doi.org/10.1109/SmartCloud49737.2020.00028].

[41] Yang Ch.-N., Chen Ch.-H., Cai S.-R.: Enhanced Boolean-based multi secret image sharing scheme. Journal of Systems and Software 116, 2016, 22-34 [http://doi.org/10.1016/j.jss.2015.01.031].

[42] Yuan L., Korshunov P., Ebrahimi T.: Secure JPEG Scrambling enabling Privacy in Photo Sharing. 11 th IEEE International Conference and Workshops on Automatic Face and Gesture Recognition (FG), 2015, 1-6 [http://doi.org/10.1109/FG.2015.7285022].

[43] Zhou J., Liu X., Au O. C., Tang Y. Y.: Designing an Efficient Image Encryption-Then-Compression System via Prediction Error Clustering and Random Permutation. IEEE Transactions on Information Forensics and Security 9(1), 2014, 39-50 [http://doi.org/10.1109/TIFS.2013.2291625].

\section{Prof. Volodymyr Barannik}

e-mail: vvbar.off@gmail.com

Doctor of Technical Sciences, Professor Department of Artificial Intelligence and Software V. N. Karazin Kharkiv National University Number of articles in national databases -750 Number of articles in international databases -112

http://orcid.org/0000-0002-2848-4524

\section{M.Sc. Natalia Barannik}

e-mail: barannik11121972@gmail.com

Postgraduate student

Scientific Researcher Scientific Organizing Department

National University of Civil Defence of Ukraine, Ukraine

Number of articles in national databases -17

Number of articles in international databases -10

https://orcid.org/0000-0001-6420-1838

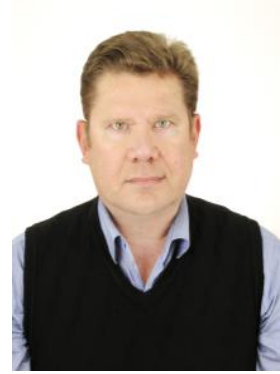

\section{Ph.D. Oleksandr Slobodyanyuk}

e-mail: slobodyanyuk.olexandr@kpnu.edu.ua

Associate professor at the Department of Computer Science in Kamianets-Podilsky Ivan Ohiienko National University.

Oleksandr Slobodyanyuk is the author more than 50 publications. His research interests include cybersecurity, data processing, algorithms and methods of video data compression.

http://orcid.org/0000-0001-5195-3053
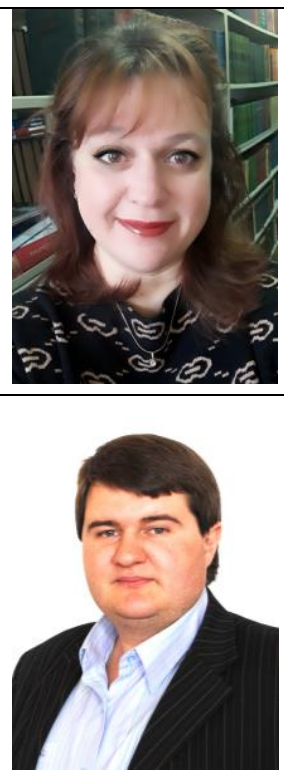

otrzymano/received: 8.11.2021

przyjęto do druku/accepted: 15.12.2021 